\title{
Biotesting chronic toxicity of waters of surface sources of water service as to presence of Ceriodaphnia affinis Lilljeborg and Allium cepa I.
}

\author{
E. Arystarkhova, \\ Ph. D. of Biological Science \\ Institute of Agroecology and Environmental Management of NAAS, \\ Metrological Str., 12, Kyiv , 03143, Ukraine \\ email: ella.aryst@gmail.com
}

The purpose. To raise selfdescriptiveness of biotesting waters of surface sources of water service due to use of test-kit made of Ceriodaphnia affinis Lilljeborg and Allium cepa L. Methods. Biotesting the quality of waters using standard and own procedures. Results. Test-reactions on fixation of Ceriodaphnia affinis and leaf-creation of Allium cepa proved damage effect of waters of water reservoirs of river Teteriv on living organisms. Conclusions. For testing quality of waters of surface sources of water service it is offered to use test-kit made of $C$. affinis and $A$. Sulfur. On the basis of responses of test-objects indexes of toxicity are calculated which reveal specificity of responsivity of Ceriodaphnia affinis and Allium cepa on 8th and 15th day to toxic chronic effect of these waters.

Key words: quality of waters, surface sources of water service, biotesting, C. affinis, A. cepa, index of toxicity, chronic effect.

In our time in the field of waters from the surface sources of water supply and drinking water biotesting it is considered the priority to create sets of sensitive organisms related to different levels of biological organization [1-4]. By the most widespread objects, plugged in sets are bacteria, algae, higher plants, protozoa, crustaceans, fish and others [5-10]. Obligatory representatives of such test kits should be amphibians (frogs, tritons and others). Thanks to the morphological structure of external covers, they have an increased sensitivity to dangerous water components. To exclude additional influences on these organisms during the biotesting you should be used as objects in the early ontogenesis - at the stage of the larva (tadpole).

In light of the above, in the experiments conducted by us compared on a sensitiveness to total water toxicity of frogs tadpoles of two types: marsh frog (Rana ridibunda Pallas, 1771) and african clawed frog (Xenopus laevis Daudin, 1802), that are model organisms and recommended to the use in the genic engineering is conducted, but did not yet get sufficient wide distribution in the biomonitiring of waters from the surface sources of water supply and drinking water. For the first time, for assessing the toxic effects of water using frogs, the proposed scale of toxicity levels tested on invertebrates [8] and fish [9], which is fully consistent with SSanRN (State sanitary rules and norms) 2.2.4-171-10 [10], has been applied.

Goal. An increasing information of waters from the surface sources of water supply and drinking water biotesting method owing to the use of african clawed frog larvae.

Materials and methods of research. In order to realize the research objective, a comparative analysis of the biotesting of water toxicity was carried out, a sample of which was selected in prepared dishes from the Denyshivske reservoir and Vidsichne water intake of Teteriv river and from the clean water reservoirs (CWR) of CE "ZhytomyrVodokanal" in April 2016 [10]. After sampling the water was poured into aquariums (10 $\left.\mathrm{dm}^{3}\right)$ and formed control and test groups according to the following scheme:

- Control group - a test of a settled (24 hours) tap water;

- Test group D-1: water samples - from the Denyshivske reservoir;

- Test group D-2: water samples - from the Vidsichne water intake;

- Test group D-3: water samples - with CWR $5000 \mathrm{~m}^{3}$;

- Test group D-4: water samples - with CWR $20000 \mathrm{~m}^{3}$. 
Test Objects: larvae of marsh frog (R. ridibunda) and african clawed frog (X. laevis), $\mathrm{n}=20$.

Retention: in aquariums, $10 \mathrm{dm}^{3}$ of water, the concentration of oxygen in which is not less than $6 \mathrm{mg} / \mathrm{dm}^{3}$, the temperature $+20^{\circ} \mathrm{C} \pm 2,5^{\circ} \mathrm{C}$, and the density of planting - individual $/ \mathrm{dm}^{3} ;$. in conditions of natural light and replacement of water of appropriate quality every 2 days.

Feeding: animal feed (mosquito larvae, sludge worm).

Test Reaction: immobilization $\left(I_{M}\right)$, including mortality of individuals.

Exposure: acute lethal toxicity - for 4 days and short-term chronic toxicity (short-term chronic toxicity) within 8 days.

Biotesting: daily calculation of active and immobilized (including dead) individuals from the 1 st to the 8th day.

Experiments were carried out in 3-time repeat, using standard techniques and own developments [3-5, 79]. The obtained data were compared with the control. For each experimental water sample, the toxicity index (\%) for the SSanRN 2.2.4-171-10 was calculated using the well-known formula [10]. The water toxicity index should not exceed $50 \%$ regardless of the test objects used in the studies.

Research results. For the biotesting of water with the relatively not high level of toxicity of the special attention deserve organisms that constantly are in a water environment and able quicker and clearer to react on an action even of insignificant concentrations of pollutants. Such requirements african clawed frogs that at all stages of metamorphosis conform to, and also after his completion conduct the exceptionally water way of life. Besides they always give preference to clean water, and in case of her contamination and impossibility of migration, stop to propagate. Therefore exactly african clawed frogs it is necessary to compare to the kinds of aborigines in relation to informing of determination on them toxicity of little muddy waters.

As test organisms, they tested for sensitivity to toxic components of water 2 species of tadpoles of marsh ( $R$. ridibunda) and african clawed ( $X$. laevis) frogs for the test-reaction of immobilization of individuals, the advantage of which, in comparison with many other frogs reactions, is the simplicity of its determination for the calculation of the number of active and immobilized individuals. For the receipt of tadpoles of marsh frogs entrapped adult individuals in clean reservoirs, taking away females that was contained in a spring water during three months. In the same water in preparatory period were and females of african clawed frogs that before were in aquariums, in the comfort for them terms of laboratory maintenance (for 7 females of every kids).

Comparative analysis of biotesting with the larvae of $R$. ridibunda and $X$. laevis of waters from the reservoirs of the Teteriv river and the CWR of Communal enterprise "ZhytomyrVodokanal" $(n=20)$

\begin{tabular}{|c|c|c|c|c|}
\hline \multirow[t]{2}{*}{ Test groups and figures } & \multicolumn{4}{|c|}{ Toxicity after immobilization of test objects (T, \%): } \\
\hline & R. ridibunda & toxicity level & $X$. laevis & toxicity level \\
\hline \multicolumn{5}{|l|}{ Acute toxicity } \\
\hline D-1 (Denyshivske Reservoir) & absent & $A_{d} T L$ & 32,20 & LTL \\
\hline D-2 (Vidsichne water intake) & absent & $A_{d} T L$ & 30,10 & LTL \\
\hline D-3 (CWR 5 000) & absent & $A_{d} T L$ & 26,10 & LTL \\
\hline D-4 (CWR 20 000) & absent & $A_{d} T L$ & 25,98 & LTL \\
\hline Exposure duration, days & 4 & - & 4 & - \\
\hline \multicolumn{5}{|l|}{ Chronic toxicity } \\
\hline D-1 (Denyshivske Reservoir) & 29,92 & LTL & 61,20 & $\mathrm{~A}_{\mathrm{v}} \mathrm{TL}$ \\
\hline D-2 (Vidsichne water intake) & 28,30 & LTL & 59,30 & $A_{v} T L$ \\
\hline D-3 (CWR 5 000) & 23,90 & LTL & 50,00 & LTL \\
\hline D-4 (CWR 20000$)$ & 24,11 & ATL & 51,19 & $\mathrm{~A}_{v} T L$ \\
\hline Exposure duration, days & 8 & - & 8 & - \\
\hline
\end{tabular}

Note: $T-$ index of water toxicity (in relation to control); levels of toxicity of water: $A_{d} T L-$ admissible, LTL - low, $A_{v} T L$ - average.

A comparative analysis of the environmental effectiveness of biotesting on guppies and danio of water samples taken in the reservoirs of the Teteriv river and the clean water reservoirs (CWR) at the Communal enterprise "ZhytomyrVodokanal" is presented in the table. 
The obtained data indicate that the test organism proposed for conducting the assessment of the water is tadpoles of $X$. laevis by the reaction of immobilization of individuals more sensitive to the determination of water toxicity than tadpoles of $R$. ridibunda. According to the biotesting data, the scale of the water toxicity levels proposed by us is used, which can be used both for the determination of its acute and chronic toxic effects [8, 9]: $1-25 \%$ - admissible level of toxicity; $26-50 \%$ - low toxicity; $51-75 \%$ - average toxicity; $76-100 \%$ high toxicity.

During a biotesting on the basis of $R$. ridibunda tadpoles immobilization the low level of chronic toxicity of experimental waters in within $25-50 \%$, but on the basis of $X$. laevis tadpoles immobilization the low level of acute lethal toxicity $(25-50 \%)$ and the average level of chronic toxicity $(51-75 \%)$ is defined.

The highest value of the toxicity index was detected in determining the chronic effect of water in the reservoir of Denyshivske, somewhat lower - in the water intake of Vidsichne (test group D-2) of Teteriv river. The determination of the acute effects of water in these groups also revealed higher levels of toxicity compared with the levels of toxicity of drinking water (test groups D-3 and D-4). Biotesting with african clawed frog larvae was on $28,60 \%$ average (in the acute study) and $28,86 \%$ (in the chronic study) more effective than testing on marsh frog larvae.

Consequently, under the same conditions of biotesting with $R$. ridibunda and $X$. laevis, the latter showed a significantly higher sensitivity to the toxic components of water sources of water supply and drinking water in the conditions of the Communal enterprise "ZhytomyrVodokanal".

\section{Conclusions}

In the conducted researches the possibility of informing increase of biotesting method of waters from the surface sources of water supply and drinking water biotesting method is confirmed with the use of $X$. laevis larvae that appeared in the conditions of the Communal enterprise "ZhytomyrVodokanal" more sensible to the relatively low levels of contamination (in average to $28,60 \%$ in acute lethal tests with exposition time 4 day and to $28,86 \%$ in short-term chronic tests with exposition time 8 day) comparatively with $R$. ridibunda larvae.

\section{Biblography}

1. Osmalenyi M.S. Holovkov A.M., Naniieva A.V., Verholias M.R. (2015). Kompleksna otsinka toksychnosti vodnykh zrazkiv za dopomohoiu roslynnykh i tvarynnykh test-orhanizmiv. Faktory eksperymentalnoi evoliutsii orhanizmiv. t.16. S. 74-77.

2. Pat. 10804 A Ukraina, MPK G 01 N 33/18; G 01 N 21/76. Sposib kompleksnoho vyznachennia henetychnoi bezpechnosti pytnoi vody / V.V. Honcharuk; zaiavnyk ta patentovlasnyk V.V. Honcharuk; zaiavl. 5.11.2015, opubl. 11.04.2016, Biul. № 7.

3. Szczerbinska N., Galczynska M. (2015). Biological methods used to assess surface water quality. Arch. Pol. Fish. № 43. - P. 185-196.

4. Radic S., Gregorovic G., Stipanicev D., Cvjetko P. et al. (2013). Assessment of surface water in the vicinity of fertilizer factory using fish and plants. Ecotoxicology and Environmental Safety. № 96. P. 32-40.

5. Skok S.V. (2015). Otsiniuvannia yakosti pytnoi vody $\mathrm{m}$. Khersona metodom biotestuvannia. Ahroekolohichnyi zhurnal. № 2. S.26-30.

6. Stetsiuk L.M. (2013). Vykorystannia metodiv bioindykatsii ta biotestuvannia dlia otsinky stanu vodnykh ekosystem. Visnyk Natsionalnoho universytetu vodnoho hospodarstva ta pryrodokorystuvannia. Vyp. 2 (62). «Silskohospodarski nauky». S.175-181.

7. ISO 10706: 2000 Water quality. Determination of long term toxicity of substances to Daphnia magna Straus (Cladocera, Crustacea). $-26 \mathrm{p}$.

8. Arystarkhova E.O. (2017). Ekspres-otsinka potentsiinoi nebezpeky vody metodom biotestuvannia na Daphnia magna S. // Visnyk ahrarnoi nauky. № 2. - S. 50-54. 
9. Arystarkhova E.O. (2017). Ekspres-otsinka toksychnosti vod poverkhnevykh dzherel vodopostachannia z vykorystanniam ryb Danio rerio // Rybohospodarska nauka Ukrainy. № 3 (41). S. $17-25$.

10. DSanPiN 2.2.4-171-10 «Hihiienichni vymohy do vody pytnoi, pryznachenoi dlia spozhyvannia liudynoiu» / \# 452 / 17747. - MOZ Ukrainy. Derzhavni standartni normy ta pravyla / [chynnyi vid 1.07.2010 r.]. $-50 \mathrm{~s}$. 